\title{
Greek Migrations along the Ionian Coast (Southern Italy)
}

\author{
Maurizio Crudo \\ University of Groningen
}

\begin{abstract}
In the previous century, ancient migration was explained on the basis of the occurrence and quantities of imported archaeological artefacts, and with interpretations made in alignment with the ancient written sources. This was so too with the Greek migration into Southern Italy, often referred to as 'Greek colonization'. This paper will focus on the relations between indigenous peoples and Greek newcomers in Southern Italy, taking the Sibaritide area as its focal point, as well as on the methods for identifying these foreign newcomers through the analyses of the archaeological record. From the end of the ninth century BCE, a Euboean-Levantine presence is detectable in the Western Mediterranean, including Northern Africa, Spain and Italy. In the first half of the eighth century BC in the Sibaritide, a Greek-indigenous coexistence emerged in the settlement of Timpone della Motta. This coexistence entailed a shared and mixed cultural framework at the site, which is reflected in the local pottery production. Based on the study of the ceramic technology, this paper seeks to shed light on the possibilities and limitations of technological analysis for identifying migration features in the archaeological record.
\end{abstract}

Keywords: Greek Colonization, Cultural Encounters, Technological Transfer, Mobility, Pottery Hybridization

\section{Introduction: why migrating?}

The mobility of peoples, objects and ideas has been a driving force for human groups since ancient times. The choice of settling in a new place implies knowing its strategic position, the availability of natural resources and raw materials in the area, as well as its degree of connectivity with other groups. However, in order to infer trade networks and exchanges from the archaeological record, evidence has to be rather straightforward: imports should be present in both areas involved in the process. On the other hand, evidence for migration relies on a complex analysis of cultural, artistic and technological similarities between two or more regions. As Elena Isayev pointed out recently, framing a historical process and categorizing it under a singular event can hide the variety of relations between locals and outsiders (Isayev 2017: 138). To explore the social and cultural impact of migration, mobility and cultural exchange, we need to focus on the wider archaeological record and from a diachronic view. In the Sibaritide area, which is the focal point of the present contribution, the Achaean colony of Sybaris was established around the end of 
the $8^{\text {th }}$ century BCE (Fig. 1). However, this was not the first encounter the locals had with foreigners travelling from the Aegean area. On the contrary, as was the case for several indigenous settlements overlooking the Sibaritide plains, Timpone della Motta had already since prehistoric times been in contact with various groups participating in Mediterranean trade connections (Bettelli 2002). Increasingly, scholars have stressed the interconnection of italic populations, suggesting cultural transmission and networks, basing their observations on both archaeometric analysis and parallels of formal elements within the pottery production (Ippolito-Attema in press; Ippolito 2016; Jones et al. 2014; Levi et al. 1999).

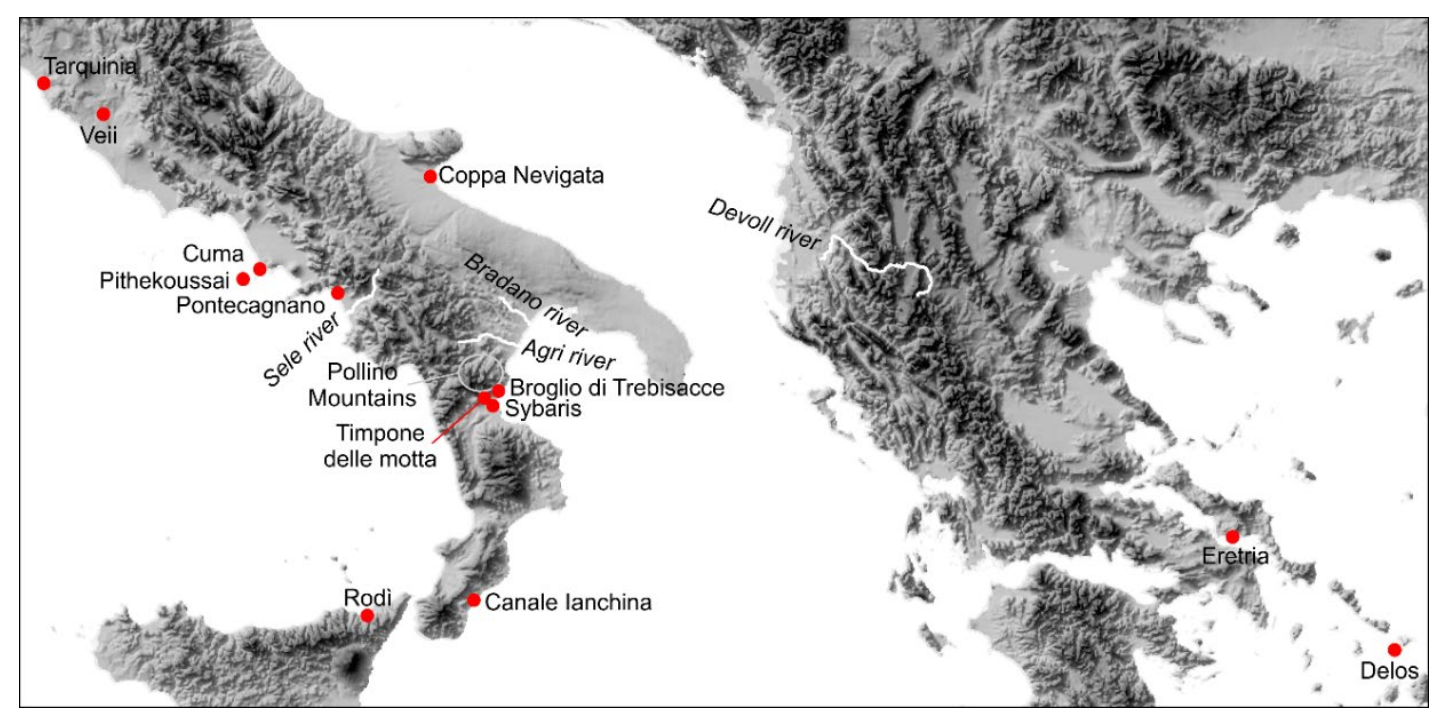

Figure 1. Sites mentioned in the text, illustration by E. Bolhuis (GIA)

\section{Explaining patterns}

Traditionally, Greek-indigenous relations have been evaluated on the presence of Greek ceramics at indigenous sites, in combination with the information provided by the ancient written sources. In these references usually the indigenous persons are represented as a naive and passive watchers of the stage wherein the Greek members act as main characters. This is natural, perhaps, given the Greek writer's inclination to describe the context just from a Greek view, as they address a Greek audience. Masked by such an approach, it is easy to overlook the fact that Greek pottery could have been transferred in a range of ways, some of which do not even include any actual Greek involvement. In addition, it is important to keep in mind that often Greek pottery only makes up a small part of the total settlement assemblages. What is more, the archaeological evidence refers to everyday life, which was of no or little interest to the Greek ancient sources and their readers. A case in point is the occurrence of Middle Geometric Euboean skyphoi, which is considered as evidence for a direct Euboean involvement at sites along the Tyrrhenian coast and - to a lesser extend - in Apulia, Sicily and along the Ionian coastline of Calabria. However, the presence of these vessels alone does not provide a straightforward argument for the presence of Greek immigrants in the area since - as noted above - Greek pottery could have been spread abroad in different ways. In the case of Apulia, the Euboean pottery found here seems to be an evidence of a Corinthian presence, as these last 
dominated the commercial contacts with the indigenous groups of the Salento region. Euboean pottery thus would have travelled along with Corinthian traders, not with Euboeans. In fact, Apulia does not seem to have been involved in the westwards activities of Euboean travelers. On the other hand, in the light of the subsequent establishment of Euboean settlements at Ischia and Cuma, we may assume that several indigenous sites along the Tyrrhenian coast, among which notably is Pontecagnano, might have been in direct contact with Euboean Greeks. Between the end of the $8^{\text {th }}$ and the $7^{\text {th }}$ centuries BCE, the integration of foreign patterns in the basic composition of grave goods in Pontecagnano shows strong connection with Euboean milieux (Cerchiai \& Cuozzo 2016).

More details are needed to set forth the case of Pithekoussai. Based on the stratigraphic observations made during the excavations by Giorgio Buchner and David Ridgway, an accurate matrix has been recently released by Valentino Nizzo (Buchner \& Ridgway 1993; Nizzo 2007). Up until now the settlement has been considered in traditional scholarship as a Greek foundation by focusing on Greek imported objects, but the evidence does not exactly confirm this statement. Using Nizzo's matrix, Lieve Donnellan (2016) has pointed out how tomb type, objects and rituals in Pithekoussai are largely related to a Tyrrhenian indigenous connection and only later and to a lesser degree to a Corinthian one. As Gosselain (2016: 194) argued, connectivity itself is not an explanation, rather it should be conceived as a "structural framework" through which exists a "possibility for the circulation of people and cultural items". Exotic objects usually draw much more attention than common ones; therefore, the two sets are not treated equally in analysis. Consequently, Greek pottery is usually overestimated, but it cannot explain by itself any ethnic or cultural identity in the settlement where it is found. In other words, trade and traded objects do not imply ethnicity. Accordingly, Corinthians could exchange Euboean pottery, just as the other way around Euboeans could trade, for example, Levantine goods.

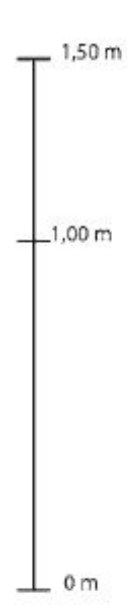

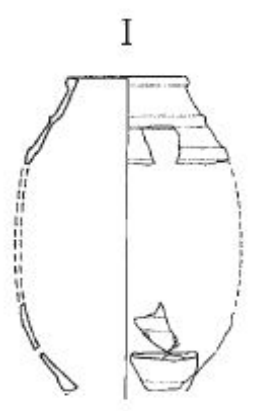

Recent Bronze Age
II

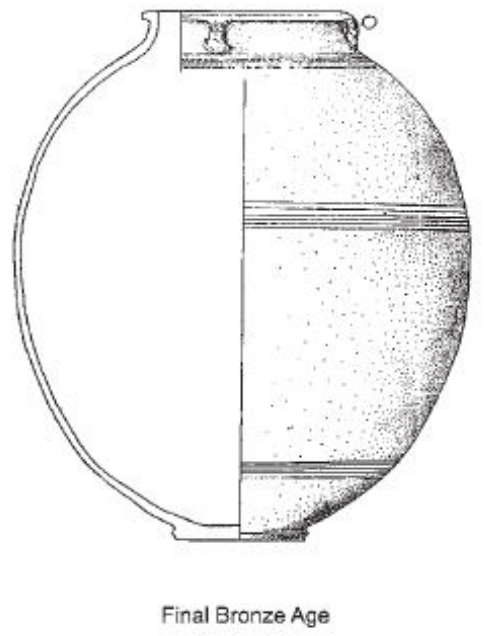

III
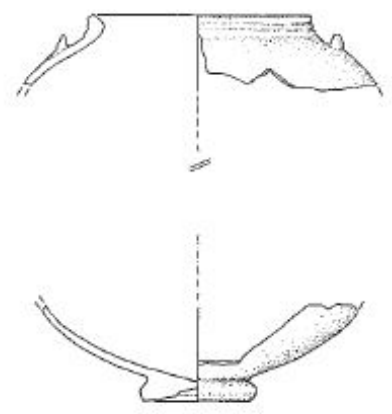

Early Iron Age

Figure 2. Pithoi, after Schiappelli 2015, fig. 1a p. 232 
Firm evidence for migration can be obtained by studying local pottery production, drawing on both Greek style and Greek shape repertoires. In the case of the Sibaritide, research on material from indigenous centres along the Ionian coast has shown that workshops producing Aegean-style vessels in local clay were active during the Bronze Age. The production in question is labelled "Italo-Mycenaean" and consists of locally manufactured vessels, which are so closely related to Mycenaean pottery in style and execution that they look like Greek imports. The same phenomenon has also been observed for the production of large storage jars (dolii) (Fig. 2), which have been interpreted as being produced by immigrant Greek potters (Schiappelli 2015, 2006; Levi \& Schiappelli 2004; Guglielmino 1999; Tabò 1998; Tenaglia 1994).

Renato Peroni has suggested that these products are derived from Aegean models as a result of a movement of skilled artisans from Greece to the Sibaritide, where they established a workshop, either permanently or temporarily (Peroni 1994: 846-847). As Schiappelli pointed out, it is hard to establish whether Greek potters: 1 - settled for longer periods within the indigenous communities; 2 - only stayed long enough to transmit their knowledge and techniques to indigenous craftsmen; or 3 - worked as travelling artisans moving from one indigenous centre to another in order to respond to the demands of indigenous customers (Schiappelli 2015: 240. See the considerations on mobility in Gosselain 2016: 195-199). According to Emma Blake a technological transfer can only take place after a period of continuous relations between "willing tutors and learners" (Blake 2016: 192). Hence, a product that shows signs of technological transfer is in reality the consequence of an already passed period of continuous relations between the cultural groups in question. However, this does not indicate per se a permanent foreign presence at the site, just the introduction of the new technology. Who the bearers of the new technological know-how are, remains an open question. A case in point would be, for instance, Broglio di Trebisacce (CS), where within the Late Bronze Age material several shells of murex (Heraplex trunculus), likely related to dyeing activity, were found. Since this dyeing technique was mostly used among the Phoenicians, one would immediately connect the presence of these molluscs to the Levantine production of purple fabric. However, the well-known contacts between the Aegean area and Broglio di Trebisacce allowed Margarita Gleba to suggest that this technology was actually brought to Italy by the Mycenaeans (Gleba 2008: 80-81). The huge amount of murex found at the indigenous site of Coppa Nevigata (FG) in contexts dated to MBA3, but prior to that already present from the beginning of the settlement in the 19th century BCE, shows how difficult is to understand the spread of this technology (Cazzella et al. 2005: 179-181). In fact, it could have passed slowly through several indigenous communities.

\section{Artefacts as evidence of migration}

Can archaeological finds indicate migration? In order to answer this question, we should first understand the complex framework of the social, economic and ritual life of a settlement by evaluating the archaeological record in its entirety. Until now, the most welltrodden path has been to analyse contexts permeated by cultural meanings, such as tombs. 
In Calabria, most of data collected come from scattered tombs and necropolis areas, while the settlement they once belonged to has often not been identified (Pacciarelli 2004: 447452). This does not allow a balanced analysis of the material culture. At least the presence of grave goods that deviate from tradition is easily detectable. In Pithekoussai, for example, through the examination of the fibulae type in S. Montano, Buchner concluded that a high percentage of women were local (Buchner 1975: 79). The fibulae repertoire does indeed show a heterogeneous cultural framework. In support Guzzo rightly argued that local production imitates the mainland indigenous repertoire and to a lesser extent Greek models. Considering the whole repertoire, however, a significant amount of fibulae were seen to be imported. Within the imports, Guzzo (2012: 519) assigned several specimens to an Oinotrian cultural background. Together with the askos from tomb 325, which shows a characteristic Oinotrian decorative pattern, best known at Timpone della Motta, these could represent an emblematic example of indigenous imports used by an indigenous woman, who had left her birthplace for the new residence at Ischia and who was later buried along with her private possessions.

A parallel case in point could be established with the burial Temparella 8 in the Macchiabate necropolis (Zancani Montuoro 1983: 29-40). Here, the buried person seems indeed to have had close links with the Greeks. This grave is located within the Temparella mound, a tumulus in which the burials were arranged based on kinship. The grave position points towards the deceased being part of an extended aristocratic family. The female tomb T8 does not show any indigenous vessels or local jewelry, but contains a globular pyxis and a kotyle, both Corinthian LG I, a SOS amphora with an Aramaic inscription, a bronze bowl, several scarabs, glass and amber beads from pendants, rings, together with ivory plates and five so-called 'a staffa lunga' fibulae. Corinthian kotylai are likewise present in graves T79, T88 and Uliveto 15. However, in these last three graves the Greek vessels seem to be in addition to typical local vessels, perhaps linked to the Greek manner of wine consumption (Saxkjaer \& Jacobsen 2014: 260-264). Anyway, the wealth of goods in tomb T8 led Marianne Kleibrink to interpret the burial as belonging to a woman from a rich family of traders, or from a family in which one of the adults was most likely of Greek origin (Kleibrink 2004a: 66 \& 2004b: 567). On the other hand, Jan Jacobsen (2007: 67) has suggested that the T8 deceased could be a Greek woman married to a man of the indigenous elite. This interpretation points towards a mixed marriage, as opposed to a male Greek colonizer and a female indigenous concubine/slave, as has previously often been assumed (Saltini Semerari 2016). Furthermore, the two cases indicate the mobility of goods and people - especially how goods move with people - which necessarily can further include a movement of ideas, technology and traditions. Mobility of goods and people surely contributed to an increasing social complexity in the local indigenous sites. Foreign trade, especially in luxuries, might have helped local élites to attract followings and encourage surplus from them. The creation and development of the market as a place of wealth and influence encourage and assist rulers or chiefs to control and perhaps monopolize trade, wielding power and thus increasing political centralization and specialization of functions (Kipp \& Schortman 1989). These settlements show a well- 
structured network of craft production systems linked to the environmental exploitation of resources within a wide area controlled for both economic and strategic issues.

At the sites along the Ionian coastline of northern Calabria, different pottery fabrics related to specific social functions are already present from the Late Bronze Age onwards. In this period, indeed, pottery production increased intensively. Common technical traits such as the use of fine clay, the adoption of the wheel and firing at a high temperature are usually displayed in the so-called "Mixed Italian Products" (Jones et al. 2014, especially 456-457 and tables 1.2 and 6.7.). Italo-Mycenaean, Grey ware and dolia exhibit the new techniques. These procedures are deeply interrelated with the indigenous impasto tradition in shapes, thus producing characteristic vases such as the carinated cups or olla of different classes (Bettelli \& Levi 2003: 443-448; Bettelli 2002: 101-104; Bettelli \& De Angelis 2002; Bettelli \& De Angelis 1998; Vagnetti \& Panichelli 1994: 407-410). Even the most common shapes in impasto fine ware now appear wheel-turned, revealing a trend to a stricter standardization (Giardino 1994: 259). Isabella Damiani related the size and style homogeneity visible in South Italian RBA pottery to a self-awareness of the local craftsmen actively engaged in new technologies (Damiani 1991: 21-23, 2004, 2010: 443445). X-ray Diffraction analysis on a carinated cup from Broglio di Trebisacce revealed that it had been fired at a very high temperature. This might indicate that complex kilns for impasto pottery production were used on a regular base (Levi et al. 1999: 221.). However the role of the local élites must be stressed. They

[....] displayed their social relevance and power using a particular type of table ware, of exotic origin, which looked completely different from the local handmade pottery from a technological point of view, but at the same time could satisfy the indigenous taste also reproducing traditional shapes (Jones et al. 2014, p. 456. See also Bettelli \& Levi 2003).

A similar conclusion could be reached for the dolia production. This should be linked to the groups that achieved socio-economic success from the spread of new farming approaches and better storage organization (Peroni 1983: 250-251). Perhaps when evaluating migration from archaeological remains, we should indeed be more careful in deductions drawn from single objects. Nevertheless, by analyzing data more deeply and in far greater numbers, we can hope to deal with complex situations that are more close to reality.

\section{Early Iron Age pottery hybridization}

Pottery showing shared cultural features (forms and decoration) can perhaps be regarded as better evidence for migration. As Carla Antonaccio argued, there is a dichotomy between material culture and identity as they mutually shape each other (Antonaccio 2010). Hybrid pottery demonstrates that foreign patterns are already assimilated by a local community. As Boardman suggested, no one copies anything deemed useless and potentially alien to the current usage (Boardman 2004). That should imply that no one replicates what he does not know or appreciate. In this sense, in addition to his previously acquired technical expertise, a potter must be aware of the customs and practices of the 
site in which he works, in order to successfully meet the local market demand. That is to say that cultural meanings and social values are as important as practical know-how. That is why one produces or paints a vessel - with the aim of making a meaningful and attractive product for the local market. Hence, it may be deduced that the society in which hybrid pottery is produced may include different ethnic groups. These coexisting individuals may have shared traditions, social customs and rituals in order to create a common repertoire. After all, each vessel has a meaning: it embodies the social, cultural, economic and craft context in which it was produced. Once different ethnic groups adapt to each other, their material culture blends.

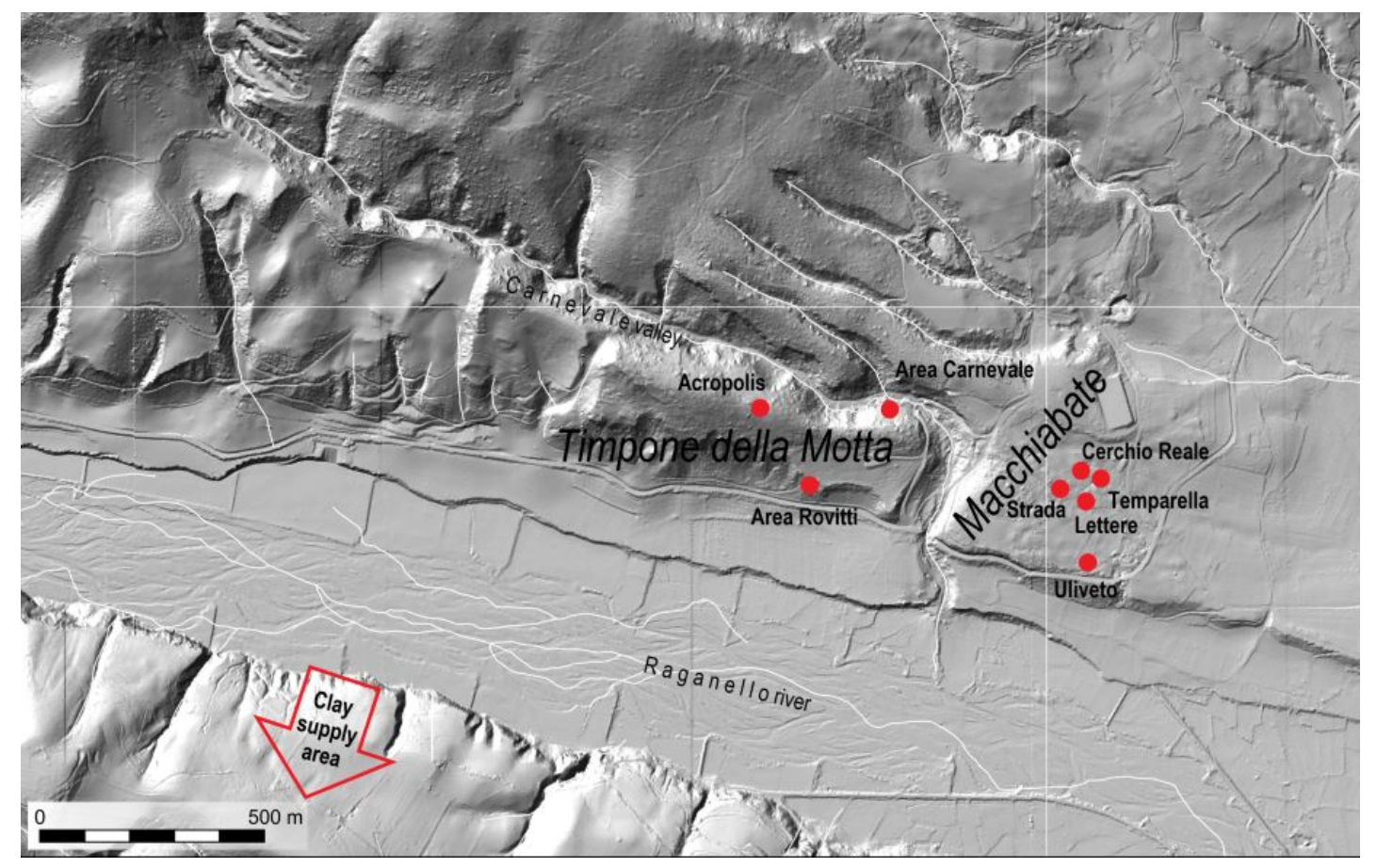

Figure 3. Timpone della Motta map, illustration by E. Bolhuis (GIA). Lidar data collected by EUFAR in 2008, and reproduced here by permission of the K.U. Leuven

\section{Iron Age pottery production at Timpone della Motta}

Different pottery classes are present at Timpone della Motta (Francavilla Marittima, CS) during the first half of the $8^{\text {th }}$ century BCE (Fig. 3). Besides a local production, imports occur and stimulate copying and the development of separate fabric. Different abilities and knowledge are needed to manufacture the fabrics used in impasto ware, matt-painted or Oinotrian-Euboean potteries. These fabrics, indeed, require distinct technical skills at every step in the operational sequence, from clay collection to drying process, from shaping to kiln firing. Zancani Montuoro identified a kiln fragment among the Temparella tumulus stones during the excavation in the Macchiabate necropolis. She interpreted it as a sign of the presence of a pottery workshop close to the necropolis area (Zancani Montuoro 1977: 94-106; 1983: 9-12, 57). Later, several misfired fragments of "Greek-inspired" pottery were found during the Groningen Institute of Archaeology excavation at the acropolis on Timpone della Motta. 


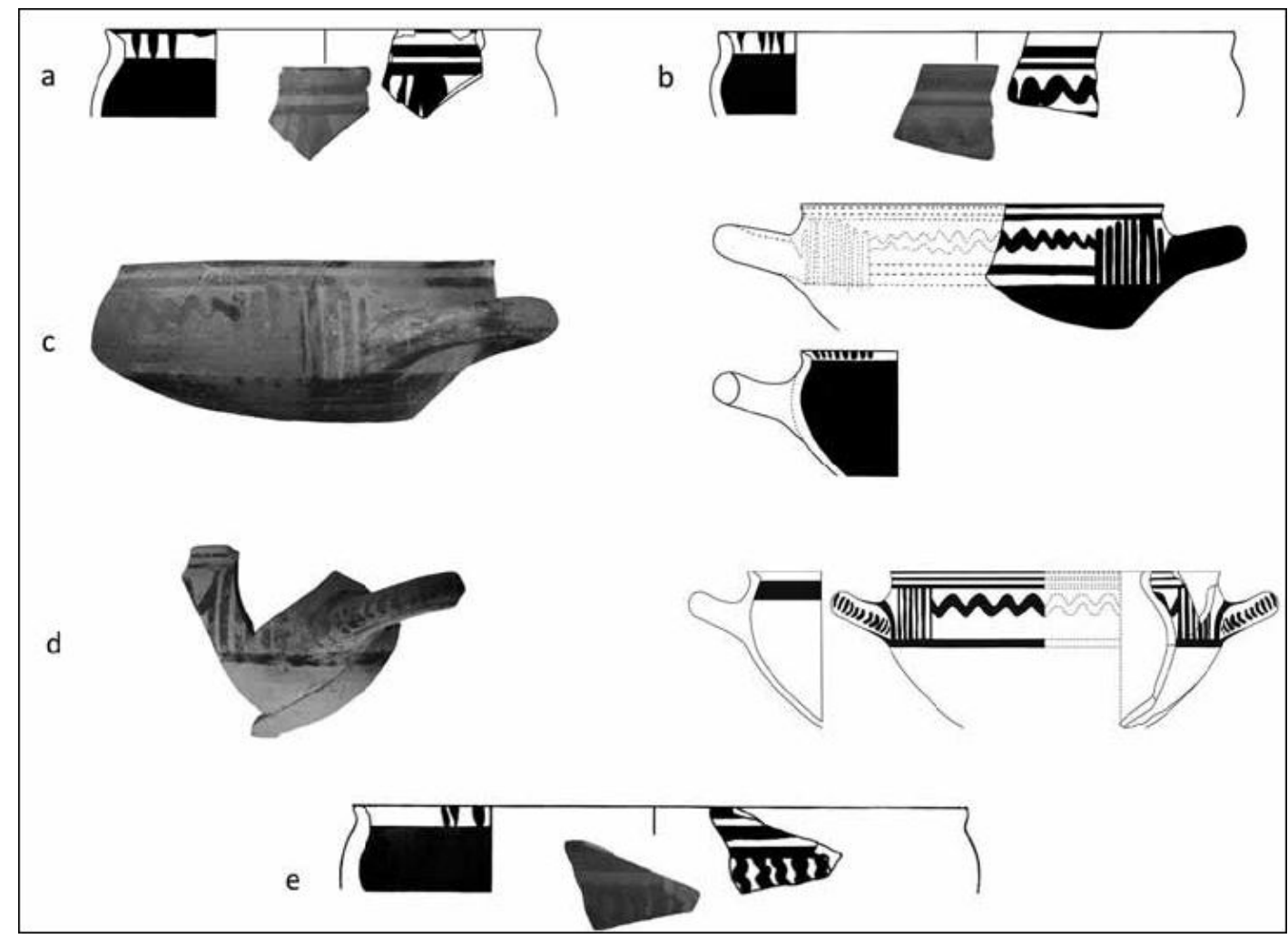

Figure 4. Oinotrio-Euboean skyphoi. a: type 2b; b: type 2a; c-d: type 3a; e: type 3b (after Jacobsen \& Handberg 2012, fig. 5.)

These finds show unequivocally that their production place should be located within the settlement, perhaps in an area not far from the Macchiabate necropolis or from the acropolis (Mittica et al. 2007: 29-34.). In the 2007, RAP surveys along the southern slope of Timpone della Motta traced a huge amount of $8^{\text {th }}$ century BC pottery aligned with the trench for the 1959 Eiano aqueduct (Raganello Archaeological Project, GIA project. See Ippolito 2016; Attema \& Ippolito 2017). Several fragments of kilns and at least two in situ furnaces were identified across this area, upstream from the present-day Road 263 (Jacobsen et al. 2009a: 90). This area is located $3 \mathrm{~km}$ from the clay supply area, identified on the opposite bank of the Raganello river in what is nowadays Lauropoli territory (Andaloro et al. 2011). In 2009 and 2010, excavations conducted in the vicinity of the kiln area disclosed a huge assemblage of pottery, calling therefore for further archaeological investigations. The remains of two eighth - seventh century BCE huts and a massive amount of pottery fragments have been found in the so-called Area Rovitti, together with artefacts from the Late Bronze Age. The pottery belongs to several distinctive wares, such as impasto, and a levigated fabric with geometric painting, both of local and of Greek styles, or imported. Moreover, the presence of cooking stands and spinning tools supports the idea that we are dealing with household remains. At the same time, misfired or defective fragments and a vessel containing the remnants of refined clay (interpreted as a container for the clay-slurry used in barbotine), link the two structures to the nearby kerameikos area (Jacobsen \& Handberg 2012: 710). The occurrence of workshops producing various pottery types in the area demonstrates the existence of hybrid products alongside typically 
local items of manufacture (Crudo 2018). I shall discuss each product type in turn in the following paragraphs.

\section{Oinotrian-Euboean pottery}

This term refers to the geographical location of the production and does not indicate an indigenous involvement in the production (Jacobsen et al. 2009a: 94). Oinotrian-Euboean pottery is a locally produced ware, usually considered to have been inspired by Greek Geometric models, especially Euboean (Jacobsen 2007: 39). This production generally consists of traditional Greek shapes, like the skyphos. From a high, almost vertical rimmed type, it develops towards a shorter one, close to the protokotyle form (Fig. 4). This process is in accord with a similar development of shapes in Greece during the Geometric Period (Coldstream 1968: 23, 87).

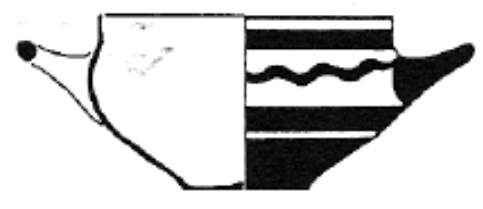

Canale-Janchina
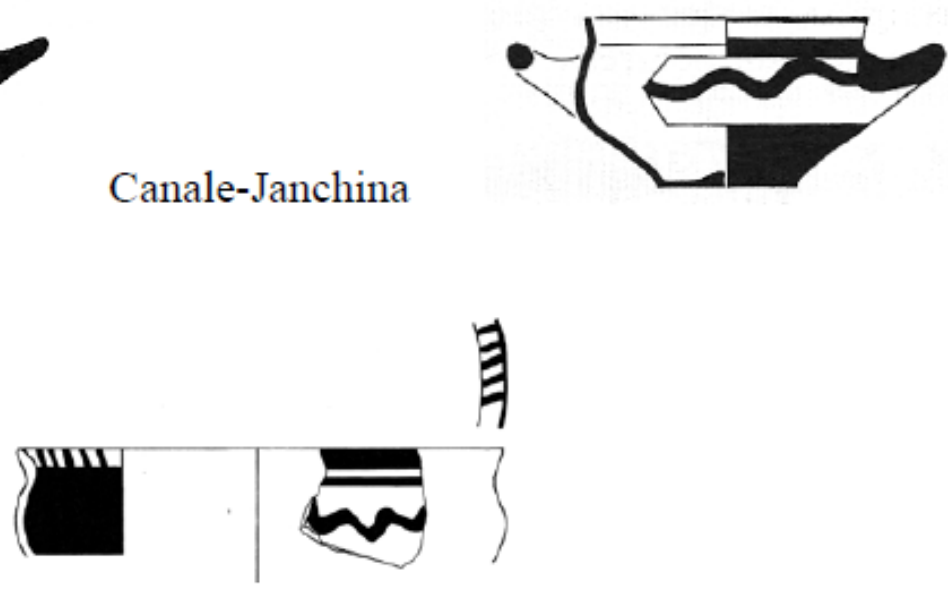

Francavilla Marittima

Figure 5. Skyphoi parallelel: FMM and Canale Ianchina, after JACOBSEN et al. 2009b, fig. 5.

The decoration looks uniform, with the constant ornamentation of a horizontal wavy band in a panel, except for the à chevron motif, which occurs in types such as $2 \mathrm{~b}$ and $3 \mathrm{~b}$ (Jacobsen et al. 2009b: 210-212; Crudo 2012: 39). The wavy band as the main motif between handles appears to be a link between Timpone della Motta types and the Canale Ianchina production in South Calabria (Fig. 5) (Mercuri 2004: 34-35, 46; fig. 69-70).

In Greece, the wavy band occurs on cups from Eretria (Verdan et al. 2008: Pl. 31 n.121, p. 165; Pl. 42 n. 173, p. 176) and Delos (Dugas \& Rhomaios 1934: PL. XXVI A, 2.). The skyphoi production from Francavilla appears standardized both in shape and decoration. The only vessel that shows a different ornamentation pattern is vessel HY94RA263 (Fig. $6 \mathrm{a}-\mathrm{b})$. The vessel was fired without applying a layer of gloss on the inside, just as the external surface was unpolished - two processes that usually take place before the firing. 

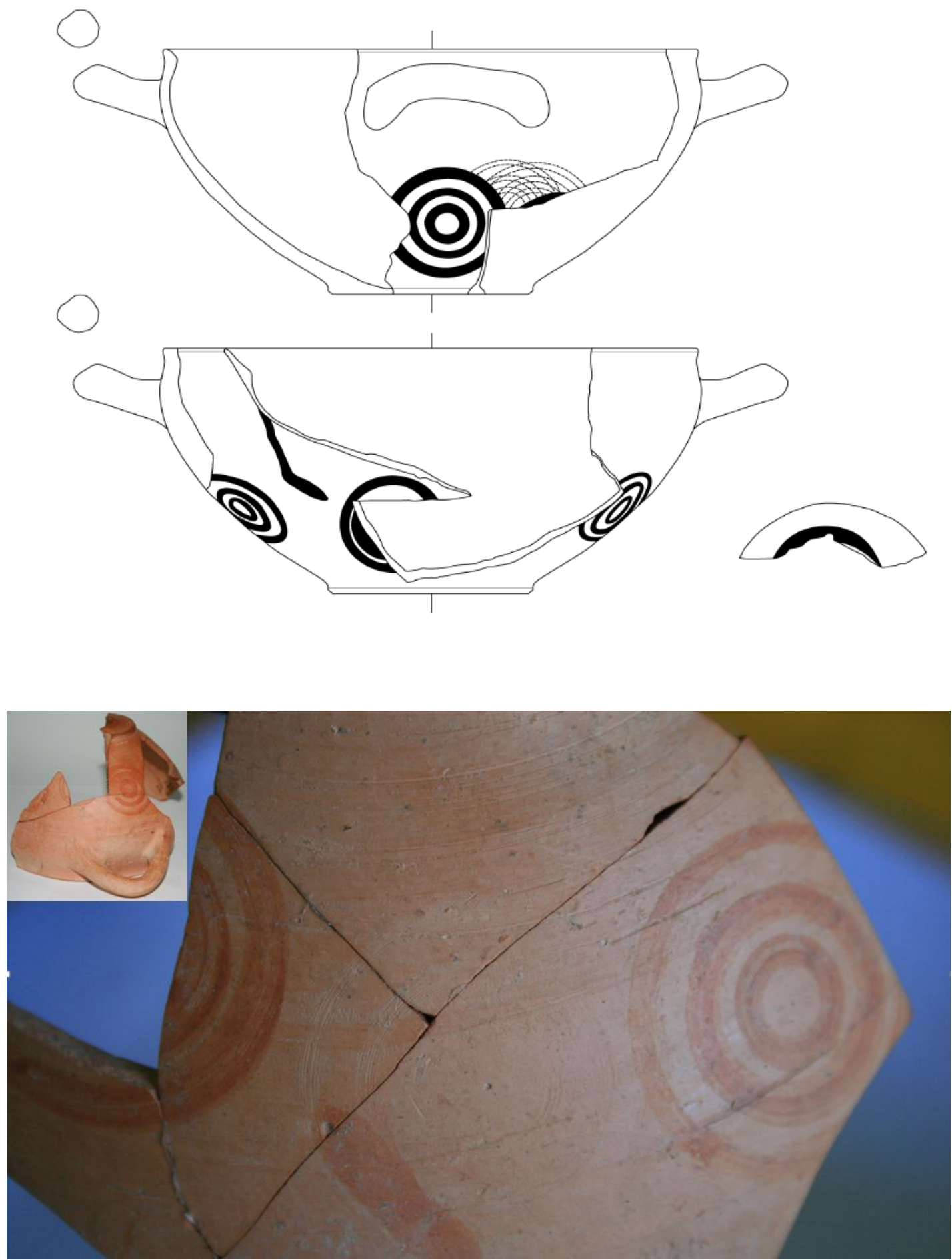

Figure 6. Skyphos HY94RA263. Illustration by the author, photo Groningen Institute of Archaeology (ab).

The potter planned to decorate the lower part of the body of the vessel with a row of concentric circles, but the decoration was applied and removed several times, probably because of the difficulties in applying the ornament in a uniform sequence. Smaller concentric circles often appear on the lip of craters and cups: however, these ones are unusual both for their intended size and position on skepphoi. Interestingly, the same decoration occurs on the lower part of the body of type 1 and type 2 of the Oinotrian- 
Euboean scodelle (Jacobsen et al. 2009b: 208). These vessels are one-handled bowls. However, here I prefer the Italian term scodella, as it has been mostly used in the previous literature. This is a typical indigenous shape of distinctive protohistoric Italian background. In the Lucanian area and in South Campania, most of the matt-painted scodelle are decorated with 'a tenda' motif. In Calabria the decoration is more variable and the 'a tenda' motif occurs together with wavy bands, typical of Oinotrian-Euboean scodelle (a volume about the wavy band decoration on Oinotrian pottery from Francavilla was recently published as a summary of the Kleibrink excavation 1991-2004 on the Timpone della Motta, Kleibrink et al. 2012). Oinotrian-Euboean scodella type 1 presents a wavy band on the upper part of the body. Wavy banded scodelle - both matt-painted and OinotrioEuboean - have been found together in context AC18.04/AC18.09 on Timpone della Motta, together with a type 1 skyphos dating to the beginning of the $8^{\text {th }}$ century BCE (Jacobsen et al. 2009b: 211). Scodella type 2 instead displays crosshatched lozenges separated by groups of vertical wavy bands on the lip. Concentric circles are evident on the lower body as in type 1. Greek-style productions imitated the scodella shape in ItaloGeometric fabric all over Italy. Direct parallels can be established for the Italo-Geometric production of Pontecagnano (SA). Just as for the scodelle type 1 from Francavilla, those specimens from Pontecagnano present concentric circles on the lower part of the body and one or two wavy bands on the upper part (Fig. 7) (d'Agostino \& Gastaldi 1988: 4748).

\section{Oinotrian Geometric pottery}

Although I have already used the term 'matt-painted', I prefer the term 'Oinotrian Geometric' to emphasize a period and a location of the production, rather than a technical characteristic. I here switch freely between the two names, using them as synonyms. A

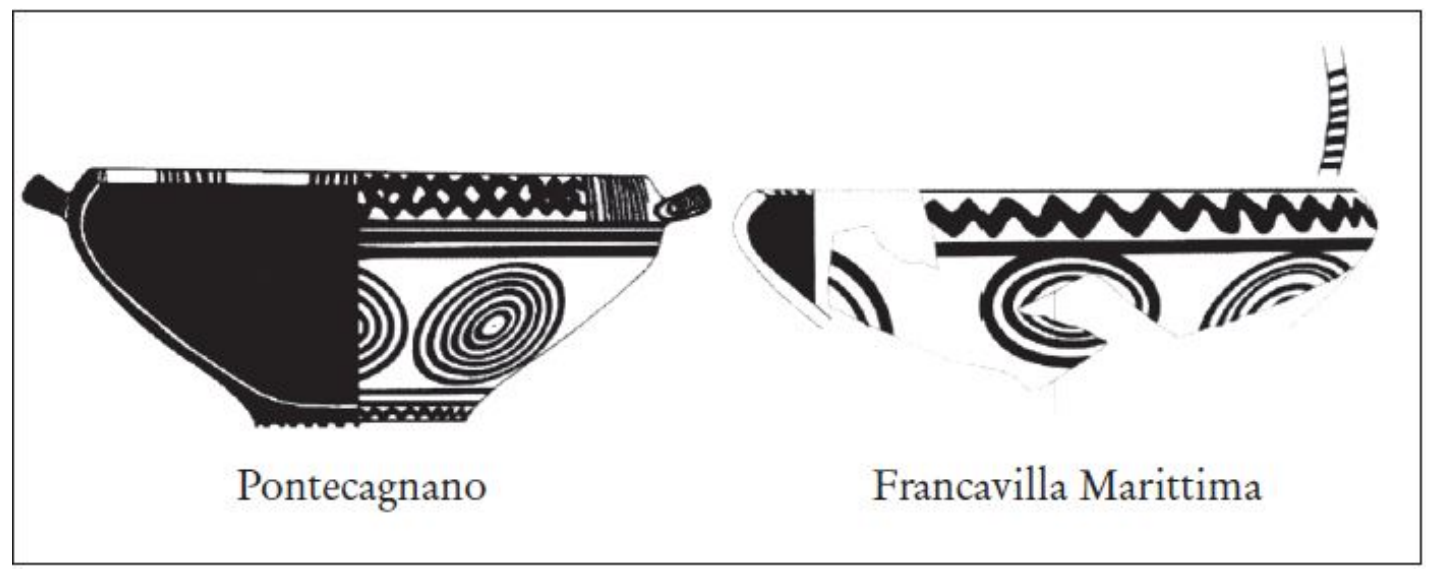

Figure 7. Scodella type 1 and parallel from Pontecagnano, after Jacobsen et al. 2009b, fig. 1.

matt, dark decoration on a light background is the characteristic of this fabric, usually hand-made or on a slow-wheel. Local Geometric pottery appears to share features with the local and traditional Proto-Geometric repertoire (Yntema 1990: 38). In addition, Bettelli has rightly argued that the Sibaritide Oinotrian Geometric pottery has no relationship with the Greek Geometric style of product. On the contrary, the matt-painted production lies within a local craft tradition, which originates from the LBA Aegean-style 
production. With the collapse of the Mycenaean world, the Oinotrian Geometric fabric found an opportunity to develop in its own way (Bettelli 2009: 29). Relations with transPollino Oinotrian contexts and with Iapygian sites beyond Bradano led to new decoration schemes. Continuous contacts with Greek and Levantine craftsmen also led to new technical devices, mostly visible through the spread of wheel-thrown pottery and in the firing at higher temperatures. These technologies seem to have been set aside after the Mycenaean contact. The higher temperature in the firing process may lead in some pots to a grey core and a metal-like sound when struck (tests on this pottery are in preparation for publication). Biconical shapes are well-represented in the matt-painted repertoire with variable patterns on the neck: wavy band or 'a tenda'. Based on the Area Rovitti stratigraphy, the former pattern-type appears to be more ancient than the latter, which could be dated after the second half of the eighth century BCE (Crudo 2012: 200). The truncated cone-shaped neck fragment HY90RA139 shows a cross pattern (Fig. 8).
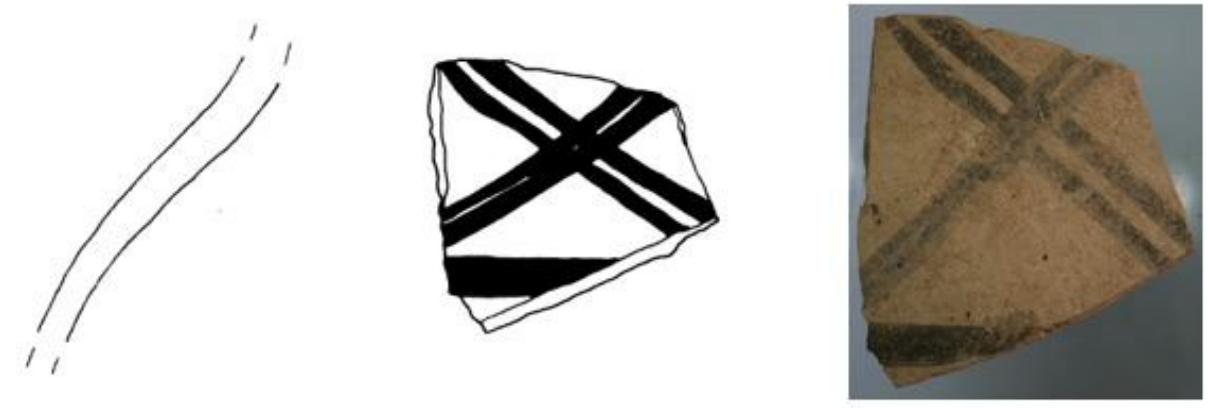

Figure 8. HY90RA139. Cross pattern. Illustration by the author, photo Groningen Institute of Archaeology

This cross-motif is well-known at Francavilla from Area Rovitti, Area Carnevale and from some vessels in tombs T40, T85 and U7 in the Macchiabate necropolis (Quondam 2009: 153, fig. 3.2-4). The same motif calls to mind those incised on some loom weights in the building Vb at Timpone della Motta (Kleibrink 2006: 151-152, fig. 49.9a and 49.9b). The design likely takes inspiration from what is known in the Rodì necropolis in Sicily. Here it appears cut into oinochoai and scodelle (Bernabò-Brea 1967: 224, 226, fig. 21.4-5,9,23 and 7.25). This theme is well-represented at Eretria too on cups and craters ${ }^{1}$. In Italy, a cup from Veii Quattro Fontanili shows the same pattern (Cavallotti Batcharova 1965: 106, figg. 36.e and 114). A single instance of a motif of crosses inserted into a row of horizontal dashes is present on a one-handled cup in tombs 7107 and 6500 in Pontecagnano (Bailo Modesti \& Gastaldi 1999: 42-43, figg. 9, 10, tav. 3.8. The authors consider this motif Calchidian, cf. d'Agostino 2014: 184). Moreover, as a secondary motif in a panel, it adorns an oinochoe body fragment and an amphora from Tarquinia (Canciani 1974: tav. 18 fig. $7-$ 8 and tav. 36 fig. 7.). A cross-pattern in a panel separated by triglyphs is described on two

\footnotetext{
${ }^{1}$ Cups: Verdan et al. 2008: Pl. 41, n. 169, p. 175; Pl. 51, n. 233, p. 185; Huber 2003: v12, p. 32, Pl.101; as a secondary motif: Verdan et al. 2008: Pl. 66, n. 328, p. 200; with a zig-zag row: Verdan et al. 2008: Pl. 6, n. 9 , p. 140; with a row of birds: Verdan et al. 2008: Pl. 51, n. 234, p. 185; Huber 2003: v18, p. 33, Pl. 101. Craters: Verdan et al. 2008: Pl. 27, n. 106, p. 161, Popham et al. 1980: Pl. 54,63, n. 248, Pl. 54, n. 252; as an encircled cross: Popham et al. 1980: Pl. 53, n. 242
} 
Italo-Geometric amphorae from Canale (Mercuri 2004: 34, 37, fig. 95-96). The kantharoscup is another typical shape of the $8^{\text {th }}$ century BCE Francavilla production (Fig. 9). This shape occurs at Apulian sites from the $9^{\text {th }}$ century BCE, perhaps through trans-Adriatic contacts, as the shape originates from the Devollian LBA kantharos-like type (Colivicchi 2004: 23-28; Gori 2018). However, in its decoration the kantharos-cup adopts a fringe style typical of and local to Francavilla (Zancani Montuoro 1977: 78).

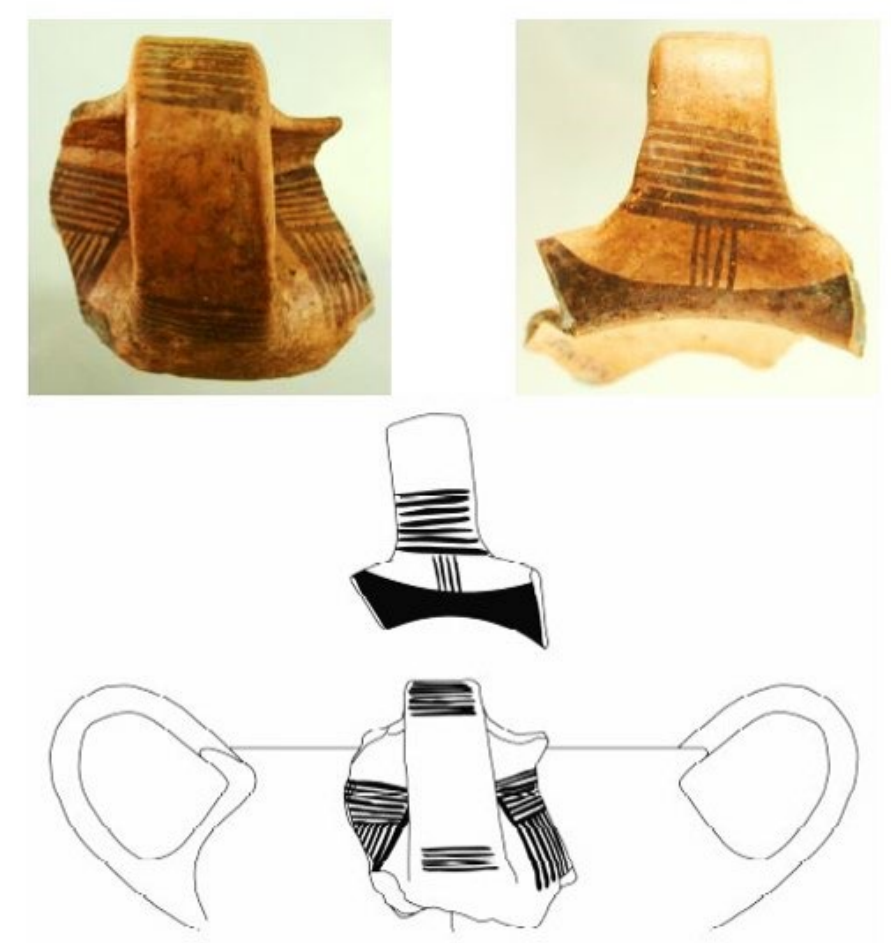

Figure 9. Kantharos-cup SM215/20C from the acropolis. Fringe style. Illustration by G. P. Mittica, photo Groningen Institute of Archaeology.

The two ribbon-shaped handles, level with or over-topping the rim, suggest for this vessel a similar use as the kantharos had among the Greeks, most likely in wine consumption by the locals. The Oinotrian Geometric production came under eastern influence from the Agri valley in the Lucanian area and from Daunian-Iapygian sites, but still developed in its own manner. Together with imported artefacts, it seems to demonstrate an East-West connection among people, trade and techniques between the Adriatic coast and the Eastern Pollino area.

Here, through mountain passages (see Colelli 2015 for the Timpone della Motta area, and Matteucci 1984 for Broglio di Trebisacce area), it was possible to move northwards, towards South Campania and the Sele plain, or southwards through the indigenous sites towards the Sila Mountains and Southern Calabria. Contacts between the Salento area and the Sibaritide have been already highlighted by the identification of a group of imported artifacts at Francavilla and by an olla found in the deepest layer of Sibari-Stombi (Kleibrink et al. 2013: 50-67; Jacobsen et al. 2009a: 89; Vanzetti 2009: 186-188, fig. 3). 


\section{Conclusions}

In the first section, an anthropological point of view about migration was laid out. Then, after a summary of some case studies, an argument about objects and their evidence in the recognition and comprehension of the subject under review was developed. At this point, the present case study based on Timpone della Motta and two different pottery fabrics were introduced.

This brief overview on the pottery production in the Sibaritide during the $8^{\text {th }}$ century BCE reveals how different were the technical traditions between the Oinotrian-Euboean and Oinotrian Geometric products. Manufacturing techniques and social connotation related to the two material cultures are likewise different from each other. The co-occurrence of the products at the same site allows for new insights on the models used to explain traditionalism and hybridization. Between the Late Geometric and the Proto-Corinthian phase (in absolute chronology 740-690 BCE), the Oinotrian Geometric pottery production shows elaborate and complex decorations, sometimes being wheel-thrown and fired at high temperatures, as detectable from the grey-core and the metal-like sound of the fragments. The vessels are not slipped with pure clay, as was in the case with the previous production characterized by its pale-yellow exterior. The surface with its pink/cream color is instead visible. What is more, the decoration is now painted in a brown-red shade instead of the previous black. The matt-painted pottery between the end of the $8^{\text {th }}$ century BCE and the beginning of the $7^{\text {th }}$ includes the same shapes and patterns, but with new technical processes that imply technological transfer. Cultural influences can be detected with the Lucanian and Iapygian areas, where the first trans-Adriatic and Aegean inputs were first restructured in a local idiom and then thus transmitted Westwards. The Oinotrian-Euboean production continued to be characterized by Greek shapes, but also absorbed local features. The decoration remains broadly true to Greek prototypes, but at the same time it tries to cater for the taste of the local populations, as is implied by the overwhelming presence of wavy and horizontal bands.

To conclude, the transmission of technical expertise and decorative developments seen in the different workshops suggests a permanent presence of immigrants. Pottery workshops at Timpone della Motta in Francavilla did not just produce vessels perfectly copying Greek prototypes, but further explored shapes and decorations in hybridized vessels. The analysis of their fabrics permits us to determine the existence of a local artisan milieu in which Greek and indigenous potters exchanged techniques, methods and meanings in an intense and creative context. This framework reveals a multicultural society that was undergoing change, and where several influences were adopted and converted into a unique common style. Immigrants and locals came together and thus laid the foundation for the later colonial establishment.

In this paper, I have tried to make clear how difficult it is to understand migration in ancient times. The problem is twofold. Firstly, though evaluating migration as reflected in ceramic classes or single objects looks at first sight an easy task, yet, in fact, it is actually 
the easiest way to go astray. Instead, a thorough analysis of the archaeological record, combined with an approach that uses both interregional and diachronic differences and similarities to assess migrations, is more likely to give better insights into ancient times. Interregional approaches allow for a comparative analysis between different micro- and macro-regions, while the diachronic perspective helps one to read the events in the area involved in the light of previous and later social and cultural dynamics. Secondly, the representation of immigrants as a uniform ethnic group, and the bearers of different ceramic technologies and new ways of social interactions, is likewise confusing. To characterize the Greeks as expert artisans in the making of wheel-made vessels, or as passionate wine lovers is misleading and provides a rather lop-sided interpretation of Greek society, as of course not all Greeks were artisans and surely they were not all heavy imbibers at symposia.

Today, as in the past, migration is a complex phenomenon in which people with different backgrounds, education, attitude, religion, beliefs, tradition, trends, eating and cooking styles are involved. Migrants from nominally the same country, for example, could come from different areas and traditions within it and so could have experienced different ways of 'belonging' to that country. A question in this third issue of Ex-Novo has made a strong impression on me: "what place do and should archaeologists have in the debate on migration?' I guess we should act as a reminder to society that migration is a phenomenon in which people with different backgrounds interact. This interaction produces fresh knowledge that can be passed on to future generations. Archaeologists can help people today to understand that migration characterizes humanity, and as such it is not something to be feared, though it does require to be explained and understood. It demands regulation and hospitality, rather than boundaries and excluding barriers. Everybody should take Terence's words to heart and say proudly "bomo sum, bumani nibil a me alieni puto". That is in my opinion the most valuable contribution archaeologists can make to today's society: make people aware of what humans did in the past.

\section{Acknowledgments}

I would like to express my gratitude to $J$. K. Jacobsen for allowing me to study the pottery from Timpone della Motta. Again to him, G. P. Mittica, S. G. Saxkjaer and the rest of the team in Francavilla for the constant help and support. I would also like to thank Lieve Donnellan for her careful reading of my manuscript and her many insightful comments and suggestions. Finally, warm thanks go to the editors of this journal, especially M. Gori and M. Revello Lami for their observations and notes.

\section{References}

Andaloro, E., C. M. Belfiore, A. M. De Francesco, J. K. Jacobsen \& G. P. Mittica, 2011. A preliminary archaeometric study of pottery remains from the archaeological site 
of Timpone della Motta, in the Sibaritide area (Calabria - Southern Italy), in Applied Clay Science 53(3): 445-453.

Antonaccio, C. M., 2010. (Re)defining ethnicity: culture, material culture, and identity, in S. HAles \& T. Hodos (eds.), Material culture and social identities in the ancient world, Cambridge: Cambridge University Press 2010, 32-53.

Atтema, P. A. J. \& F. Ippolito, 2017. Il Progetto Archeologico Raganello (RAP) Sviluppo insediativo di lunga durata nell'hinterland della Sibaritide protostorica, in L. CiCALA \& M. PACCIARELLI (eds.), Centri fortificati indigeni della Calabria dalla protostoria alletà ellenistica, Atti del Convegno 16-17 gennaio 2014 Università degli Studi di Napoli Federico II, Napoli: Naus Editoria Archeologica, 69-80.

Bailo Modesti, G. \& P. Gastaldi (eds.), 1999. Prima di Pithecusa. I più antichi materiali greci del golfo di Salerno. Catalogo della mostra - 29 Aprile 1999. Pontecagnano Faiano, Museo Nazionale dell'Agro Picentino.

BernabÒ-BREA, L., 1967. La necropoli di Longane, in Bullettino di Paletnologia Italiana 76: 181-254.

BETTELLI, M., 2002. Italia meridionale e mondo miceneo. Ricerche su dinamiche di acculturazione e aspetti archeologici, con particolare riferimento ai versanti adriatico e ionico della penisola italiana, Firenze: All'Insegna del Giglio.

BETTELLI, M., 2009. Le ceramiche figuline nell'età del bronzo: importazioni, imitazioni e derivazioni locali, in M. Betteleli, C. De Faveri \& M. Osanna (eds.), Prima delle Colonie. Organizzazione territoriale e produrioni ceramiche specializzate in Basilicata e in Calabria settentrionale ionica nella prima età del Ferro. Atti delle Giomate di Studio, Matera, 20-21 novembre 2007, Venosa: Osanna Edizioni 17-35.

Bettelli, M. \& D. De Angelis, 1998. Produzioni specializzate a differente livello tecnologico: le tazze e le ciotole carenate d'impasto e di ceramica grigia dell'età del bronzo recente, in R. Peroni \& A. VAnzetTi (eds.), Broglio di Trebisacce 1990-1994. Elementi e problemi nuovi dalle recenti campagne di scavo, Soveria Mannelli: Rubbettino, 133-156.

Bettelli, M. \& D. De Angelis, 2002. Produzioni specializzate a differente livello tecnologico, in M. BETTELLI, Italia meridionale e mondo miceneo. Ricerche su dinamiche di acculturazione e aspetti archeologici, con particolare riferimento ai versanti adriatico e ionico della penisola italiana, Firenze: All'Insegna del Giglio, 72-95.

BETTELLi, M. \& S. T. LEVI, 2003. Lo sviluppo delle produzioni ceramiche specializzate in Italia meridionale nell'età del Bronzo in rapporto ai modelli egei e alla ceramica di impasto indigena, in Le comunità della Preistoria Italiana, Studi e Ricerche sul Neolitico e le età dei metalli. Atti XXXV Riunione Scientifica Istituto Italiano di Preistoria e Protostoria (Castello di Lipari, Chiesa di S. Caterina 2-7 giugno 2000). In memoria di Luigi Bernabò Brea, Firenze, 435-454.

BLAKE, E., 2016. Commentary: States and Technological Mobility - A view from the West, in E. KIRIATZI \& C. KNAPPETT (eds.), Human Mobility and Technological Transfer in the Prehistoric Mediterranean, Cambridge: Cambridge University Press, 181-192.

BoARDMAn, J., 2004. Copies of pottery: by and for whom?, in K. LOMAS (ed.), Greek Identity in the Western Mediterranean. Papers in honour of Brian Shefton, Leiden - Boston: Brill, 149-162. 
Buchner, G. 1975 Nuovi aspetti e problemi posti dagli scavi di Pithecusa con particolari considerazioni sulle oreficerie di stile orientalizzante antico, in Contribution à l'étude de la société et de la colonisation eubéennes, Naples: Cahiers du centre Jean Bérard, 59-86.

Buchner, G. \& D. RidGWAy, 1993. Pithekoussai I. La necropoli: tombe 1-723, scavate dal 1952 al 1961, in Monumenti Antichi LV, Serie Monografica IV, Roma.

Canciani F. (ed.), 1974. Corpus Vasorum Antiquorum. Italia. Museo Archeologico Nazionale Tarquinia, Fascicolo LV, Roma.

CAvallotti BAtcharova, A. 1965. Quarta campagna di scavo (Maggio-Giugno 1963), in Veio (Isola Farnese) - Continuazione degli scavi nella necropoli villanoviana in località Quattro Fontanili, Notizie degli Scavi di Antichità: 1965, 65-155.

CAzZella, A., C. Minniti, M. Moscoloni \& G. ReCCHiA, 2005. L'insediamento dell'età del Bronzo di Coppa Nevigata (Foggia) e la più antica attestazione della produzione della porpora in Italia, in Preistoria Alpina, Suppl. 1, 40 (2004): 177-182.

Cerchiai, L. \& M. Cuozzo, 2016. Tra Pitecusa e Pontecagnano: il consumo del vino nel rituale funebre tra Greci, Etruschi e indigeni, in G. M. Di NocerA, A. Guidi \& A. ZIFFERERO (eds.), Archeotipico: l'archeologia come strumento per la ricostruzione del paesaggio e dell'alimentazione antica. Atti del Convegno (Viterbo, 16 ottobre 2015) Università della Tuscia Complesso di S. Maria in Gradi, Firenze: Le Lettere, 195-207.

Coldstream, J. N., 1968. Greek Geometric Pottery, a survey of ten local styles and their chronology, London: Methuen \& Co.

Colelli, C., 2015. Topografia e viabilità dell'insediamento del Timpone della Motta, in P. Brocato (ed.), Note di archeologia calabrese, Cosenza, 59-70.

Colivicchi, F. 2004. L'altro vino. Vino, cultura e identità nella Puglia e Basilicata anelleniche, in Siris 5: 23-68.

Crudo, M. 2012. Analisi dei contesti della Prima Età del Ferro dal giacimento archeologico dell'Area Rovitti di Timpone Motta. Tesi di Laurea Magistrale, Università La Sapienza di Roma (unpublished).

Crudo, M. 2018. Ricezione, interazione e trasformazioni in due centri indigeni della Calabria Ionica nell'Età del Ferro. Francavilla Marittima e Canale Ianchina, in M. D'ANDREA \& M. CORRADO (eds.), Achille Solano. Ricercatore gentiluomo. Atti della giornata di studio Nicotera, 25 aprile 2015, Vibo Valentia: Adhoc Edizioni, 41-78.

D'Agostino, B. 2014. The Archaeological Background of the Analysed Pendent Semicircle Skyphoi from Pontecagnano, in M. KERSCHNER, I. S. LEMOS (eds.) Archaeometric Analyses of Euboean and Euboean Related Pottery: New Results and their Interpretations. Proceedings of the Round Table Conference held at the Austrian Archaeological Institute in Athens, 15 and 16 April 2011, Wien: Österreichisches Archäologisches Institut Wien, 181-190.

D’Agostino, B. \& P. Gastaldi (eds.), 1988. Pontecagnano. II. La necropoli del Picentino. 1. Le tombe della Prima Età del Ferro, Napoli: Annali dell'Istituto Universitario Orientale di Napoli, Dipartimento di studi del mondo classico e del Mediterraneo antico, sezione di archeologia e storia antica.

DAMIANI, I. 1991. Aspetti ceramici dell'età del Bronzo recente in Italia peninsulare e nelle isole Eolie: la facies subappenninica a trent'anni dalla sua definizione, in Dialoghi di Archeologia, terza serie, anno 9, 1991, nn. 1-2, Roma: 5-33. 
Damiani, I. 2004. Circolazione dei modelli e organizzazione della manifattura, in D. COCCHI GENICK (ed.), L'età del bronzo recente in Italia. Atti del Congresso Narionale di Lido di Camaiore, 26-29 ottobre 2000, Viareggio-Lucca 2004: 243-254.

DAmiani, I. 2010. L'età del bronzo recente nell'Italia Centro-Meridionale, Firenze: All'Insegna del Giglio.

DONNELLAN, L. 2016. 'Greek colonisation' and Mediterranean networks: patterns of mobility and interaction at Pithekoussai, in Journal of Greek. Archaeology 1: 109-148.

Dugas, C. \& C. Rhomaios, 1934. Exploration Archéologique de Délos. Les vases Préhelléniques et Géométriques, École Française d'Athènes XV, Paris 1934.

Giardino, C. 1994. I materiali dell'età del Bronzo Recente, in Peroni, R. \& F. Trucco (eds.) 1994. Enotri e Micenei nella Sibaritide. I Broglio di Trebisacce. Taranto: Istituto per la Storia e l'Archeologia della Magna Grecia, 185-264.

GleBA, M. 2008. Textile Production in pre-Roman Italy, Oxford: Oxbow Books.

GORI, M. 2018. Bronze Age and the Embedded Macedonian Question, in S. GIMATZIDIS, M. PieniAż̇ek \& S. MANGALOĞLU-Votruba (eds.), Archaeology Across Frontiers and Borderlands. Fragmentation and Connectivity in the North Aegean and the Central Balkans from the Bronze Age to the Iron Age, Orea 9: 391-440.

Gosselain, O. P. 2016. Commentary: On Fluxes, Connections and their Archaeological Manifestations, in E. Kiriatzi \& C. KNAPPETT (eds.), Human Mobility and Technological Transfer in the Prehistoric Mediterranean, Cambridge: Cambridge University Press, 193-205.

Guglielmino, R. 1999. I dolii cordonati di Roca Vecchia (LE) e il problema della loro

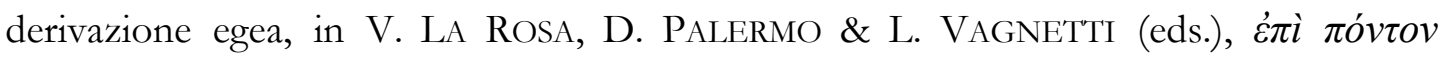
$\pi \lambda \alpha \zeta o ́ \mu \varepsilon v o r$. Simposio italiano di Studi Egei dedicato a Luigi Bernabò Brea e Giovanni Pugliese Carratelli (Roma, 18-20 febbraio 1998), Roma: Scuola Archeologica Italiana di Atene, 475486.

GuZzo, P. G. 2012. Fibule e identitá a Pithecusa, in Archeologia Classica LXIII - n. s. II, 2, 2012: 509-535.

HUBER, S. 2003. L'aire sacrificielle au Nord du Sanctuaire d'Apollon Daphnéphoros, Vol. I-II, in Eretria XIV. Fouilles et recherches. Ecole Suisse d'archéologie en Grèce, Gollion: Infolio.

Ippolito, F. 2016. Before the Iron Age. The oldest settlements in the hinterland of the Sibaritide (Calabria, Italy), PhD Thesis, University of Groningen, online.

Ippolito, F. \& P. A. J. ATtema, in press. The potential of impasto pottery studies for understanding regional settlement dynamics and cultural connectivity in Bronze Age landscapes in Italy, in Proceedings International Mediterranean Workshop "Field, Sherds and Scholars, recording and interpreting survey ceramics", Athens 24-25 February, 2017.

IsAYeV, E., 2017. Migration, Mobility and Place in Ancient Italy, Cambridge: Cambridge University Press 2017.

Jacobsen, J. K. 2007. Greek Pottery on the Timpone della Motta and the Sibaritide c. 780 to 620 BC. Reception, distribution, and an evaluation of Greek pottery as a source material for the study of Greek influence before and after the founding of ancient Sybaris, $\mathrm{PhD}$ thesis, Groningen University, online.

Jacobsen, J. K., S. Handberg \& G. P. MitTica 2009a. An early Euboean pottery workshop in the Sibaritide, in Annali dell'Istituto Universitario Orientale di Napoli, Dipartimento 
di studi del mondo classico e del Mediterraneo antico, sezione di archeologia e storia antica, Nuova Serie N. 15-16, Napoli: 89-96.

JACOBSEN, J. K., G. P. MitTiCA \& S. HANBERG 2009b. Oinotrian-Euboean pottery in the Sibaritide. A preliminary report, in M. BetTeldi, C. De FAveri \& M. Osanna (eds.), Prima delle Colonie. Organizzazione territoriale e produæioni ceramiche specializzate in Basilicata e in Calabria settentrionale ionica nella prima età del Ferro. Atti delle Giornate di Studio, Matera, 20-21 novembre 2007, Venosa: Osanna Edizioni 203-222.

Jacobsen, J. K., S. HAndBerg, 2012. A Greek enclave at the Iron Age settlement of Timpone della Motta, in Alle origini della Magna Grecia. Mobilità migrazioni fondazioni, Atti del cinquantesimo convegno di Studi sulla Magna Grecia, Taranto 1-4 ottobre 2010, Taranto: Istituto per la Storia e l'Archeologia della Magna Grecia, 683-718.

Jones, R., S. T. LeVI, M. BetTelli \& L. VAgnetTi 2014. Italo-Mycenaean pottery: the archaeological and archaeometric dimensions, CNR - Roma: Istituto di Studi sul Mediterraneo Antico.

KIPP, R. S. \& E. M. SCHORTMAN, 1989. The political impact of Trade in Chiefdoms, in American Anthropologist, New Series, Vol. 91, No. 2 (Jun., 1989): 370-385.

KLEIBRINK, M. 2004a. Towards an Archaeology of Oinotria, observations on indigenous patterns of religion and settlement in the coastal plain of Sybaris (Calabria), in P. ATTEMA (ed.), Centralization, early urbanization and colonization in first millennium BC Italy and Greece, Bullettin antieke beschaving. Annual papers on Classical Archaeology supplement 9 2004: 29-96.

KLEIBRINK, M. 2004b. Aristocratic tombs and dwellings of the VIIIth century BC at Francavilla Marittima, in Preistoria e Protostoria della Calabria. Atti della XXXVII Riunione Scientifica IIPP (Scalea, Papasidero, Praia a Mare, Tortora 29 settembre-4 ottobre 2002), Firenze: 557-586.

KLEIBRINK, M. 2006. Oenotrians at Lagaria near Sybaris, a native proto-urban centralized settlement. A preliminary report on the excavation of two timber dwellings on the Timpone della Motta near Francavilla Marittima (Lagaria) southern Italy, Accordia Research Institute: University of London 2006.

KLeibrink, M., L. BARResi \& M. FASAnella Masci 2012. Excavations at Francavilla Marittima 1991-2004. Matt-Painted Pottery from the Timpone della Motta. Volume 1: The Undulating Band Style, BAR International Series 2423, Oxford: Archaeopress.

KLEIBRINK, M., M. FASANELLA MASCI \& L. BARRESI 2013. Excavations at Francavilla Marittima 1991-2004. Matt-Painted Pottery from the Timpone della Motta. Volume 2: The Cross-Hatched Bands Style, BAR International Series 2553, Oxford: Archaeopress.

LEVI, S. T. \& altri autori, 1999. Produzione e circolazione della ceramica nella Sibaritide protostorica. 1. Impasto e dolii, Firenze: All'Insegna del Giglio.

LEVI, S. T. \& A. SCHIAPPELLI, 2004. I pithoi di ispirazione egea del tardo Bronzo nell'Italia meridionale: tecnologia, contenuto, immagazzinamento, circolazione, in E. C. DE SENA, H. Dessales (eds.), Metodi e approcci archeologici: l'industria e il commercio nell'Italia antica. Archaeological Methods and Approaches: Industry and Commerce in Ancient Italy, Bar International Series 1262, Oxford: Archaeopress, 96-108.

Matteucci, R. 1984. Pascoli estivi e tratturi nell'area di Broglio, in R. Peroni (ed.), Nuove ricerche sulla protostoria della Sibaritide, Roma: Paleani Editrice, 260-265. 
Mercuri, L. 2004. Eubéens en Calabre à l'époque archaïque, formes de contacts et d'implantation, in Bibliothèque des Écoles Françaises d'Athènes et de Rome 321, Roma: École Française de Rome.

MitTicA, G. P., S. HAndBerg \& J. K. JacobSen 2007. Ceramica malcotta dal Santuario di Timpone della Motta, in Atti della V Giomata Archeologica Francavillese (28 Ottobre 2006, Francavilla Marittima), Francavilla Marittima: 10-25.

Nizzo, V. 2007. Ritorno ad Ischia: dalla stratigrafia della necropoli di Pithekoussai alla tipologia dei materiali, Napoli: Centre Jean Bérard.

Pacciarelli, M. 2004. La prima Età del Ferro in Calabria, in Preistoria e Protostoria della Calabria. Atti della XXXVII riunione scientifica (Scalea, Papasidero, Praia a Mare, Tortora 29 settembre - 4 ottobre 2002) Firenze: 447-475.

Peroni, R. 1983. Presenze micenee e forme socio-economiche nell'Italia protostorica, in Magna Grecia e mondo miceneo. Atti del XXII Convegno di Studi sulla Magna Grecia (Taranto, 7-11 ottobre 1982), Taranto: Istituto per la Storia e l'Archeologia della Magna Grecia, 211-284. Peroni, R. 1994. Le comunità enotrie della Sibaritide ed i loro rapporti con i navigatori egei, in Peroni, R. \& F. Trucco (eds.) Enotri e Micenei nella Sibaritide. II Altri siti della Sibaritide, Taranto: Istituto per la Storia e l'Archeologia della Magna Grecia, 832-879.

Popham, M. R., L. H. SacketT \& P. G. Themelis, 1980. Lefkandi I. The Iron Age. The settlement; the cemeteries, in British School at Athens supplementary vol. 11, London: Thames and Hudson.

QuONDAM, F. 2009. La necropoli di Francavilla Marittima. Tra mondo indigeno e colonizzazione greca, in M. Bettelli, C. De Faveri \& M. Osanna (eds.), Prima delle Colonie. Organizzazione territoriale e produzioni ceramiche specializzate in Basilicata e in Calabria settentrionale ionica nella prima età del Ferro. Atti delle Giornate di Studio, Matera, 20-21 novembre 2007, Venosa: Osanna Edizioni 139-178.

SAXkJAer, S. G. \& J. K. JacobSEn 2014. Observations on Greek and Greek-inspired pottery in the Macchiabate Necropolis, in P. BROCATO (ed.), Studi sulla necropoli di Macchiabate a Francavilla Marittima (CS) e sui territori limitrofi, Università della Calabria, Rossano: 259-282.

SALTINI SEMERARI, G. 2016. Greek-Indigenous intermarriage: a gendered perspective, in L. Donnellan, V. Nizzo \& G. J. Burgers (eds.), Conceptualising early Colonisation, Proceedings of the Conference "Contextualising "early Colonisation", vol. II Bruxelles-Roma: Istituto Storico Belga di Roma 77-87.

SCHIAPPELLI, A. 2006. Dolii e magazzini tra tardo Bronzo e primo Ferro: una panoramica tra Italia meridionale e mondo egeo-mediterraneo, in Studi di protostoria in onore di Renato Peroni, Firenze: All'Insegna del Giglio, 393-398.

SChiappelli, A. 2015. Along the routes of Pithoi in the Late Bronze Age, in A. BABBI, F. Bubenheimer-Erhart, B. Marín-Aguilera \& S. MÜHL (eds.), The Mediterranean mirror. Cultural contacts in the Mediterranean sea between 1200 and 750 B.C. International Post-doc and Young Researcher Conference, Heidelberg 6th - 8th October 2012, Mainz: Römisch-Germanischen Zentralmuseums, 231-243.

TABÒ, D. 1998. I nuovi dolii dell'età del bronzo recente, in R. PERONI \& A. VAnZETTI (eds.), Broglio di Trebisacce 1990-1994. Elementi e problemi nuovi dalle recenti campagne di scavo, Soveria Mannelli: Rubbettino, 157-173. 
Tenaglia, P. 1994. I dolii cordonati, in Peroni, R. \& F. TruCCO (a cura di) 1994. Enotri e Micenei nella Sibaritide. I Broglio di Trebisacce. Taranto: Istituto per la Storia e l'Archeologia della Magna Grecia, 347-371.

VAgnetTi, L. \& S. PANiCheldi, 1994. Ceramica egea importata e di produzione locale, in Peroni, R. \& F. Trucco (a cura di) 1994. Enotri e Micenei nella Sibaritide. I Broglio di Trebisacce. Taranto: Istituto per la Storia e l'Archeologia della Magna Grecia, 373-413.

VAnzetTi, A. 2009. Notazioni sulla fine dell'età del ferro precoloniale nella Piana di Sibari, in M. Bettelli, C. De Faveri \& M. Osanna (eds.), Prima delle Colonie. Organizzazione territoriale e produrioni ceramiche specializæate in Basilicata e in Calabria settentrionale ionica nella prima età del Ferro. Atti delle Giornate di Studio, Matera, 20-21 novembre 2007, Venosa: Osanna Edizioni 179-202.

Verdan, S., A. Kenzelmann Pfyffer \& C. Léderrey, 2008. Céramique Géométrique d'Érétrie, in Eretria XX. Fouilles et recherches. Ecole Suisse d'archéologie en Grèce, Gollion: Infolio.

YNTEMA, D. 1990. The matt-painted pottery of Southern Italy. A general survey of the matt-painted pottery styles of Southern Italy during the Final Bronze Age and the Iron Age, Galatina: Congedo Editore.

Zancani Montuoro, P. 1977. Francavilla Marittima. A) Necropoli. I. Tre notabili Enotri del VIII sec. a.C.; II. Dischi compositi; III. La leggenda di Epeo, in Atti e Memorie della Società Magna Grecia, n.s. XV-XVII (1974-1976), Roma: 9-106.

Zancani Montuoro, P. 1983. Francavilla Marittima. Necropoli e ceramico a Macchiabate. Zona T. (Temparella), in Atti e Memorie della Società Magna Grecia, n.s. XXIXXIII (1980-1982), Roma: 7-129. 
